\title{
Levels of Community Cohesion: Theorizing the UK Agenda and the Implications for Policy and Practice in Schools
}

\author{
Marie Parker-Jenkins \\ University of Limerick \\ Ireland \\ Meli Glenn \\ Pearson Education, London \\ United Kingdom
}

This paper explores the concept of "community engagement," a central theme within a British research project examining the issues of cultural sustainability among faith-based schools. Discussion is informed by the views of Muslim and Jewish school community stakeholders at the time when the policy of social cohesion was being legally introduced into schools in the United Kingdom. The article provides: (a) an introduction to the context of the British government agenda on "community cohesion" (promoting greater knowledge, respect, and contact between groups within the community) in the aftermath of 9/11, the riots in northern towns in England in 2001, and the bombings in London; (b) an historical perspective on the establishment of denominational schooling in the UK with reference to Muslim and Jewish schools; (c) explication of the research design; (d) exploration of the theory and conceptualisation of community cohesion drawing on qualitative data from the study; and ( $f$ ) the implications raised for policy and practice in all schools.

\author{
Introduction \\ Background: Muslim and Jewish Schools in the United Kingdom \\ The Research Design \\ Theorizing Community Cohesion \\ Implications for Policy and Practice in Schools \\ Conclusion \\ Notes \\ References
}

\section{Introduction}

The research project ${ }^{1}$ addressed in this article, entitled "Terms of Engagement: Jewish and Muslim School Communities, Religious Identity and Cultural Sustainability," examined how Muslim and Jewish communities seek to protect themselves against threats of "identity erosion," or against Islamophobia and anti-Semitism, through influence over the education of their children in UK 
faith-based schools. In our study, we were particularly interested in how antiSemitic and Islamophobic hostility surfaced towards schools formed by Jewish and Muslim communities and how this bodes in terms of a government agenda aimed at developing greater community cohesion. This is in the context of the British government agenda on social cohesion post $9 / 11$, the riots in northern towns in England in 2001, and bombings in London in 2005. The government saw school as the place where "community cohesion" should be developed.

Recent educational reform in the United Kingdom has promoted a choice model where faith-based schools are an accepted part of a wider drive to raise educational standards by expanding parental choice. Government interest in the potential of faith communities and their organizations is reflected in developments of public policy (Furbey, Dinham, \& Farnell, 2006). Given the educational policies towards inclusion (Department for Education and Skills [DfES] 2006), religious schools must reconcile legitimate parental choice for an education for their children, which responds to community, religious, and cultural distinctiveness, with the need for inter-community understanding, tolerance, and respect. While some groups are prompted to engage across religious boundaries and to participate in wider civil society and processes of governance, others seek distance from alternative religious traditions and secular culture.

This article provides: (a) an historical perspective on the establishment of denominational schooling in the United Kingdom with reference to Muslim and Jewish schools, (b) explication of the research design, (c) exploration of the theory and conceptualisation of community cohesion across different communities, and (d) the implications raised for policy and practice in all schools.

\section{Background: Muslim and Jewish Schools in the United Kingdom}

There are over 100 Jewish schools in Britain, dating back to the $19^{\text {th }}$ century, 38 of which operate full-time with government funding (Parker-Jenkins, Hartas, \& Irving, 2005). While, similarly, there are over 100 Muslim schools, only 11 receive financial support from the state (Department for Children, Schools and Families [DCSF], 2010). Both Jewish and Muslim communities have experienced prejudice and xenophobia to an extent not experienced by other denominational school communities in Britain. Notwithstanding geographical, historical, and cultural differences, the parallel growth of Muslim and Jewish schools in the United Kingdom highlights fundamental issues of community cohesion and religious identity.

The 2001 Census revealed that in terms of religious affiliation, there are just over $1 \frac{1}{2}$ million Muslims in the United Kingdom and just under 280,000 Jews (Office of National Statistics, 2006; Weller, 2003). Due to immigration, there is a cultural heritage from different European communities, most notably the Ashkenazi (European Jews) and the Sephardi (Middle Eastern Jews), and major Jewish centres established in London and Birmingham reflect this cultural diversity (Schmool \& Cohen, 1998). In terms of Jewish schools, there are 93 full- 
time Jewish educational institutions in the United Kingdom; $41 \%$ of them are state-funded, serving approximately 30,000 children of compulsory school age (5 -16) and representing $50 \%$ of the Jewish pupil population (Miller, 2007).

Under English law, the categorisation of a school as "voluntary aided" denotes a level of government funding, including all teachers' salaries and $95 \%$ of running costs (Lankshear, 2001). There are also a variety of other types of schools: for example, academies and "foundation" schools that may or may not have religious sponsors and the remaining "community schools" that tend to be non-denominational (Education and Inspections Act, 2006). Within Jewish schools, "Pikuach," an inspection service launched by the Board of Deputies of British Jews in 1996 is the UK Jewish community's response to the Government's requirement that religious education be inspected under the framework set up by the Office for Standards in Education (Ofsted). In 2007, the Pikuach report placed emphasis on learning about other faiths reflecting the government agenda to address issues of social cohesion (Miller, 2007).

Statistically, Muslim schools have been the most expanding faith-based group. Twenty years ago there were approximately 25 Muslim schools in the United Kingdom. Today there are approximately 130, and they are mostly Sunni, which reflects the fact that only $10 \%$ of Muslim communities in Britain are Shia (Parker-Jenkins, Hartas, \& Irving, 2005; AMSUK, 2009). Of the Muslim population in the UK, approximately 350,000 are of school age (AMSUK, 2009). Collectively, Muslim schools are part of the approximately 7,000 faith-based schools in England, which include just under 5,000 Church of England and other Christian schools, 2,053 Catholic, 38 Jewish, 11 Muslim, 2 Sikh, and 1 Hindu, Seventh Day Adventist, Quaker, and Greek Orthodox schools, accommodating a third of the school population (DCSF, 2010).

While the Muslim and Jewish groups have different cultural and historic roots, they are similar in that they both are minorities seeking to sustain cultural heritage in the face of assimilationist trends. Both communities often operate in a self-imposed form of "segregation," creating a type of cultural enclave, frequently locally based, whilst engaging with the wider community on their own terms. The obligation to teach the British National Curriculum (DfEE/QCA, 1999) only falls on those schools in receipt of public funding, but the majority of Muslim and Jewish schools incorporate aspects of the national framework into their curriculum (Parker-Jenkins, Hartas, \& Irving, 2005).

Faith-based schools established on Islamic principles have developed since the immigration of the 1960s and the increased dissatisfaction with community school provision (Walford, 2001; Hewer, 2001; Parker-Jenkins, 1995, 2002; Parker-Jenkins, Hewitt, Brownhill, \& Sanders, 2007). In Britain, schools for "the masses" were established by the clergy due to government reluctance to ensure educational provision, and this tradition of denominational funding of schools has been continued more recently by Muslims (DCSF, 2010). The Jewish education system in the United Kingdom can be traced back to the mid$17^{\text {th }}$ century, when day schools were established along with synagogues; in 1855 the first Jewish day school received state funding (Miller, 2007). 
Both school communities claim they are following the steps of previous denominational groups, notably Anglican (Brown, 2003; Lankshear, 2001) and Catholic (Hornsby-Smith, 2000; Catholic Education Service, 1997), in wishing to have a school system permeated by faith. Muslim schools have tended to be the group targeted for greatest criticism in trying to follow this denominational school tradition, accessing the public purse, and in some cases allegedly teaching a "radical" Islam (Times Educational Supplement [TES], 2001; Parker-Jenkins, 2002). As we know from research into Catholic schools (O'Keefe, 1997; Catholic Education Service, 1999) and into Jewish schools (Short \& Lenga, 2002), there are different levels of engagement with the wider community by faith-based schools and their self-exclusion can be constructed to demonstrate deliberate social isolation (O'Keefe, 1997), sometimes in the form of ethnic/religious defence (Husain \& O'Brien, 1999).

The establishment of schools in the United States, for example, has constitutionally been based on the separation of church and state, but there are private academies reflective of a particular religious ethos, such as Catholicism and Judaism, and also those based on Islam which offers an alternative site of learning (Michel, 2006). Muslim schools are a relatively recent addition to the educational landscape in non-Islamic states: for example, Germany (Neilsen, 2000), the Netherlands (Walford, 2001), and Australia (Clyne, 2000). There has also been establishment of Muslim schools in the United States (Michel, 2006; Gülen, 2005) and in Canada (Zine, 2007).

Having provided a background to the study and highlighted the similarities between Muslim and Jewish school communities in the United Kingdom, we next explain the research design upon which this paper is based.

\section{The Research Design}

The main aims of the research were to answer the following questions: Why, how, and in what ways is religious/cultural sustainability regarded as critical to the school's raison d'etre; and what are the experiences of engagement and estrangement/alienation with the wider community? This was built on the previous work of Parker-Jenkins, Hartas, and Irving (2005), which raised the question, "Do we ask enough of faith-based schools in terms of community engagement on behalf of their pupils?" The fieldwork took place between 20072008, involving nine schools in the Midlands and Northern England, and over 100 stakeholder participants: senior managers, governors, teachers, parents, pupil/student focus groups, and members of the wider communities.

Methodologically, the study involved a case study of five Muslim schools and four Jewish schools being representative of primary/elementary and secondary/high school levels and incorporating a range of independent to statefunded institutions within both religious traditions. The slight discrepancy in numbers was based on a decision to include a Muslim girls' school headed by a 
non-Muslim head teacher, providing the widest spectrum of perspectives. Jewish schools in the United Kingdom tend to differentiate themselves through an added nomenclature, such as Liberal/Progressive, Modern Orthodox, Ultra Orthodox, or Zionist, depending on the community's interpretation of Jewish identity (Miller, 2001). Conversely, schools based on an Islamic ethos in the United Kingdom are normally identified under the collective term "Muslim School" although there is huge differentiation within them based on sectarian and cultural factors (ParkerJenkins, Hartas, \& Irving, 2005); elsewhere in Europe they are described as "Islamic schools" (Walford, 2001). To ensure a wide spectrum, our research included Liberal/Progressive Jewish or Modern Orthodox Jewish ethos. Within the Muslim sample schools, selection was based on an Islamic ethos, which ranged from "orthodox" to more "liberal" in terms of interpretation of religious texts; all five were Sunni due to the absence of any based on a Shia tradition (Association of Muslim Schools, 2009).

The study incorporated semi-structured interviews with stakeholders in each school and discussion groups with pupils aged between 8-18 through School Council selection or with older pupils. Children in the Muslim schools were predominantly $2^{\text {nd }}$ - or $3^{\text {rd }}$-generation British Muslims from a diversity of backgrounds: e.g., Pakistani, Bangladeshi, and Middle Eastern. Those in the Jewish schools were mostly from families established in the United Kingdom for many decades and generally representative of European backgrounds.

For the purpose of this paper we define the concept of Islamophobia as "unfounded hostility towards Islam, and therefore, fear or dislike of all or most Muslims" (Runnymede Trust, 1997, p.1). Anti-Semitism is defined as "a certain perception of Jews, which may be expressed as hatred toward Jews" (European Monitoring Centre on Racism and Xenophobia, 2009, p.1). Within our research, we were particularly interested in evidence of Anti-Semitic or Islamophobic attacks or hostility towards Jewish or Muslim school communities.

Theoretically, we employed Denham's (2001) notion of "self-segregation by choice" as it relates to "cultural sustainability" within schools. For the purpose of this discussion we define cultural sustainability as the passing on of traditions, customs, and values through the family, and the extent to which it is possible to operate in a non-Islamic or non-Jewish state. There has been a shift from the concept of multiculturalism to community cohesion (Cantle, 2006) as an ideology within the Liberal State (MacMullen, 2007). The failure of multiculturalism to deliver equitable outcomes in society and an attempt to look beyond this concept are echoed elsewhere, for example, by Hollinger's (1995) Post Ethnic America: Beyond Multiculturalism and Kincheloe and Steinberg's (1997) work on critical multiculturalism. The emphasis on "bonding social capital" (Coleman, 1994; Pugh \& Telhaj, 2007) assists in promoting shared values within the school community and a cooperative practice between the school and the home, which is perceived as lacking in non-faith-based schools. 


\section{Theorizing Community Cohesion}

Next we theorize the key issue of "community cohesion," drawing on data from our study to outline the way the terminology is used and the extent to which the concept is being realised within school communities. We defined the concept of "community cohesion" in terms of promoting greater knowledge, respect, and contact between groups within the community, and developing a greater sense of citizenship (Pearce, 2005). The data to inform our theoretical development came from in-depth interviews, classroom observation, and institutional ethos. This discussion is structured around our research project themes of "community engagement" and "the experience of hostility." "Engagement" is defined as the ability or willingness of different communities to live alongside and with each other, and to meet with, work with, and be educated with those outside of their own community (Gaine 1995). Associated with these concepts is that of "alienation," meaning withdrawal, self-imposed segregation in the name of maintaining identity or fear of others, thus to separate or dis-engage (Beckerman \& McGlynn, 2007).

For many ethnic groups, the promotion of assimilation is rejected, where names are Anglicized and the only status that matters is framed around a White Christian perspective. This is one of the reasons why faith-based schools emerged, a disillusionment with and fear of the ideologies of integration and assimilation (Parker-Jenkins, Hartas, \& Irving, 2005). Cantle (2001) maintains that a segregated society is a divided society, but perceptions of segregation in the United Kingdom are still significant and both ethnic and social in nature (Home Office, 2001). Cantle makes it clear that in spite of equal opportunities legislation and funding, the outcomes for the community were the opposite of what had been intended: "separate educational...bodies, social, language and cultural networks had meant that many of the communities operated on the basis of 'parallel lives'" (p. 9).

Of the 67 practical measures to improve community relations, Cantle summed up the proposed strategic approach as that of promoting "community cohesion." The follow-up Cantle Report (2006) attempted to evaluate progress to date. In the following section we provide highlights from our data of the impact of the community cohesion strategy on the "parallel lives" of our respondents.

The concept of "community cohesion" is linked to overlapping concepts of social inclusion and community and social capital. Taking the Cantle agenda further, the Local Government Association's (2002) "Guidance on Community Cohesion" defines the concept as one in which there is a shared vision and sense of belonging for all communities. Subsequent documents have attempted to define and expand the concept: for example, "Our Shared Futures" identifies a cohesive community as one in which there is a clearly defined vision for a city, region, or country (Runnymede Trust, 2008). The DCSF (2007) in its nonstatutory "Guidance on the Duty to Promote Community Cohesion" highlights 
educational institutions particularly as helping to achieve political initiatives:

[The] schools' role here is crucial: by creating opportunities for pupils' achievement and enabling every child and young person to achieve their potential, schools make a significant contribution to long term community cohesion. (p. 4)

Here the term "community" is defined as operating on four levels, including all stakeholders involved in the school community itself, the wider surrounding community where it is based, the United Kingdom, and the global communities.

Within these lofty aspirations, the school's contribution is seen to be through such things as "the community" and extended services. These broad themes are particularly relevant to faith-based schools, such as the Jewish and Muslim schools in our study, because schools are encouraged to interact with people from different backgrounds (DCSF, 2007).

\section{Community Engagement}

A key aspect of this study was the extent to which the sample of schools related to the wider community, and we explored this in terms of community engagement. One governor of a Muslim girls' school in our study said on the issue of community engagement:

Each year we run community harmony awards and they started after the disturbances [in 2001]. If there is...an initiative that somebody is undertaking to bring different communities together, then we ask...to nominate them...we hold a ceremony in the town hall and prizes are given to acknowledge that there are people working to bring communities together for a more cohesive harmony. ${ }^{2}$

In a focus group conducted with students in a Muslim school it was likewise observed:

....after the riots...they had different people from religions and different backgrounds come together to communicate and get to know things about each other's cultures..., so you don't have the barrier or end up hating each other.

From a Jewish perspective, a teacher in a Liberal school reported that their engagement stretches from links to the local neighborhood, to the global "and everything in-between both Jewish and non-Jewish." Similarly, a governor of a modern orthodox Jewish school said that they were involved in the community in every aspect and their children visited local churches.

Visiting and connecting with different schools and those of a different faith was an approach used by most of the schools in our study. The idea of twinning 
has been advocated for many years (Parker-Jenkins, 1995). However, the impetus to carry this out has been based on individual school response, and the difficulty of overcoming logistic and financial hurdles has meant that in many cases schools have remained culturally isolated and ignorant of "the Other." The "Other" in this case may be within as well as beyond a religious tradition. A deputy head teacher in a modern orthodox school reported:

We have been trying for some time to find a Muslim school that will engage with us. It's trying to find a liberal Muslim school because we want our children to meet moderates of other religions.

Cohesion within the faith is an important factor in this instance as a male head teacher of a modern Orthodox school said:

We are very conscious of thinking of the wider community in 3 levels; the Jewish wider community...that includes Orthodox, Ultra Orthodox, Nonobservant, Progressive, Liberal. A wider community, other faiths, and then a wider general community. English society in its multicultural mixedup self.

Parekh's (2002) concept of a "community of communities" is a useful descriptor here: groups characterized by ethnic, historical, and sectarian differences, but united by sharing the same faith. Although huge differences exist among Muslims, they have their own concept of one "community" or "ummah."

A consortium of Jewish schools represented in the study organised "Multicultural Weeks" whereby individual schools prepared work around a theme within cultural pluralism, and this was shared among others: for example, Chinese, Indian, and African-Caribbean weeks. The Internet and electronic communication were also used, with adult guidance, connecting children to broaden their awareness of the wider community.

Reaching out to the wider community was felt important by one Jewish teacher because "a lot of children that go to Jewish schools ... don't have a lot of contact with people in the wider world." An approach to address this was as follows:

There is a school across the park and we have been to it on several occasions to do assemblies on Hanukah and the Passover. They have been here as well for Divali and Eid. We also did a project on Judaism for a non-Jewish audience.

There are concepts of responsible citizenship and charitable deeds within both the Jewish and Muslim cultures based around the concept of "derech eretz," the Jewish precept which incorporates participating in society with courtesy and respect, and the Muslim notion of the ummah. These concepts are expressed in their participation in interfaith religious festivals and volunteer work within and beyond their own faith group. The chosen charities by the pupils in one Jewish secondary school were "one British-based Jewish charity, one Israeli, one nonJewish, and one African." Similarly, a Muslim school supported a range of charities including British, Palestinian, and non-Muslim charities. 
The researched schools demonstrated degrees of engagement with the "community" at local, national, and international levels on the basis of their own religious and political agenda, challenging the assumption that little engagement is taking place among faith-based schools. Different levels of engagement exist from substantive to tokenistic (long-term and funding-ensured to superficial and temporary). These efforts are reflected in the admission policies that admit Muslims and Jews from different groups within the faith tradition. For example, converted Jews in Jewish schools provide an important dimension to the terms "plurality" and "cohesion" within their faiths. Despite the common criticism that faith-based schools are ghettoised or operating in self-imposed isolation, there is a diversity of responses to "engagement" shown in both the formal and informal curriculum.

\section{Experience of Hostility}

Beyond this evidence of community engagement, our data revealed a feeling of hostility from the wider multicultural society. Sacks (2007) argues that multiculturalism emerged as a reality based on the large extent of migration towards Western countries from non-Western countries, which in turn led to the idea of "one nation, one culture" (p. 35). In our study one Muslim school principal argued:

Kids have to live and work in a society which they have to know something about. Just celebrating each other's festivals is a very facile approach-it doesn't teach respect. The kids who throw stones at me or spit at me in the street have been through a multicultural education and probably their parents have-you could say the educational system has failed them.

Hostility towards faith-based schools challenges the success in developing community cohesion. As in the United States (Larkin, 2007) and in Europe (The Independent, 2007), all schools in the United Kingdom have to be vigilant to potential attacks, and there is evidence of an increase in violence in British schools (Parker-Jenkins, 2008). However, Muslim and Jewish schools are particularly vulnerable to hostility that can be defined as anti-Semitism or Islamophobia (Runnymede Trust, 2008), and this was evidenced in our research. For example, a female Muslim teacher working in the North of England stated:

Here there are many, many Sikh women that have been attacked because people assume they are Muslim. I don't know what your religion is, but if you went out in this dress, people would assume that you are Muslim just because you have a headscarf on and they would have a go at you.

She added further with reference to community relations:

Certainly xenophobia has increased since $9 / 11 \ldots$ and here at the moment there are two issues, one is Palestine and Israel...and then there is Afghanistan, Iraq and America and so forth, and that is a separate issue. 
But it seems that they have joined the two together and they are using the word "terrorist" for everything and anything.

This was further illustrated with reference to the role of some sections of the media:

For example, if I go tonight and burn a shop and someone knew it was me, in the newspaper it would more than like say a "Muslim terrorist." If a non-Muslim, they would say it was an arson attack. Only last week .there was a man who said he had a rucksack with a bomb in it, but he was white, so what the police did was shoot him with rubber bullets... this [other] guy was walking up and down and he looked like an Asian. If he had a beard and he actually said he had explosives in his bag. They would have used live bullets on him...that is Islamophobia.

Issues of safety impact on the experience of schooling for Muslim and Jewish children, and these matters, rather than notions of religious identity, may underpin "choice," the perceived sense of insecurity that many parents feel has led them to choose religious schools as safe havens from racism (ParkerJenkins, 2002). For example, one non-Muslim teacher in a Muslim school discussed taking her pupils on school visits: "since the bombings [2005] we have to take them in a minibus, before we may have caught the train... it's a security thing."

Similarly, security for Jewish schools in the United Kingdom is taken very seriously, guided by an organisation called the "Central Community Security Trust" (Community Security Trust 2010), which respondents in our study frequently cited. One head teacher in a remote part of the countryside said, "We take advice from CST as to how secure we should be," explaining further on the point of safety in schools,

If you went to the school next door you have to press the buzzer and say who you are, you wouldn't be faced with CCTV cameras. This is what we have been advised to do. I would go so far as to say that all Jewish schools in this country have CCTV cameras... we have to be vigilant all of the time.

Associated with hostility from the outside community, a lack of acceptance was also raised, particularly among Muslim respondents. One female teacher commented:

Muslims feel under quite a lot of pressure...say today news come on and there is an explosion on a bus in London,.... it could be a petrol tank exploded but it seems that the fault only lies with Muslims and it doesn't lie with anything else, we are the cause for everything.

In addition, in terms of acceptance by the wider community,

I have been here 34 years....those people who have tried to become part of the community have been rejected....at the moment we don't think we have been accepted by the majority of the community because we are 
always being undermined, and if you are being undermined you have to associate with something else.

This view is replicated in the work of Modood (2005) in terms of a lack of belonging expressed by immigrants despite long-term residency in the United Kingdom. We believe that it is this perception and experience of being unwelcome rather than of attachment to their country of origin that diminishes a sense of belonging in British society. For both Jews and Muslims, family ties and the presence of people with similar ethnic or religious backgrounds were seen as an important reason for moving to and valuing the locality in which they lived and for which they chose the school. Recent research shows that both migrants and established Muslim residents stated that they derived a sense of security from the presence of people sharing their religion, ethnicity, or country of origin in their locality (Jayaweera \& Choudhury, 2008).

The disproportionate attention that faith-based schools receive regarding cohesion is frequently grounded in a lack of knowledge of what takes place in these schools. As all schools have been obliged to demonstrate "community cohesion" since autumn 2008, there is a need for embedding "community cohesion' into the policy framework. However, as this critique of 'community cohesion" suggests there is also a need to challenge policy because previous initiatives have been severely criticised (Troyna \& Carrington 1990; Gillborn 1995; Gilroy 1987). In terms of disengagement, there is a fear of British society, and this is seen as one of the main factors preventing minority groups from integrating fully with the host society:

...here we are a community; we are all together in the same situation, so it just builds up your self-esteem. Being in this society...you are not anything....here we are together...and we don't have to face anything" (Student, Muslim Girls' School)

Importantly, we found that hostility from the wider community was experienced by children rather than adults who frequently dismissed or underplayed the issue. For example, a Jewish teacher said:

I don't think many of the children come across anti-Semitism in their day to day lives. If it exists it is very subtle, too subtle for them to pick up on.

Probing this point further, some of the adults in the study would, however, list incidents of hostility, such as verbal abuse outside school. Some of the responses were more graphic, "you get the occasional comment ...someone may say 'Dirty Jews' or 'Yid lid'." Similarly, male pupils reported hiding the name of their school blazer when on public transport because they were afraid of bullying, and they had received derogatory comments about their genitalia. In this instance we are not talking about bullying: there needs to be differentiation between anti-Semitism and racism on top of that, which is different from bulling between children. One head teacher in our sample schools was convinced of overt prejudice: 
There is lots of evidence of anti-Semitism in the wider society.... If I ask most of my parents do they have non-Jewish friends I would say at least $70 \%$ probably don't have a single non-Jewish friend. A large number of our families associate within not a religious, but within an exclusively Jewish social community, all the people they see and most of the people they know are Jewish.

However, for some of the children travelling by themselves outside of this "social community" there were negative experiences. Some teachers challenged whether these hostile incidents were in fact based on anti-Semitism or on "normal" behavior among school children. For example, one Jewish teacher argued:

I'm not surprised in the slightest that it does happen, but at the same time I wonder what these Jewish children on the buses are doing to wind other children up? I am Jewish and I'm all for Jewish people but at the same time they can't be just sitting there quietly. I don't believe they are. Confident Jewish kids think they are it. I am sure they do wind people up...Are they, Jewish kids sitting on the bus saying 'you f'ing Christians'?

This view that bullying is standard behaviour "just between kids and their school uniform" may underplay the xenophobia experienced by children. From the pupil focus groups we heard of many examples of anti-Semitism and Islamophobia from the wider community and that alternatively, their school was a safe haven. For example, Muslim girls said that outside school they had their hijabs or head scarves pulled off accompanied by shouting like," you f'ing Muslim." This generated a sense of a "them-and-us" culture, and safety rested within the school and the community.

As noted from the discussion so far, the pursuit of community cohesion is problematic: success in the short- or medium-term is unlikely. From our research we found that the concept of "engagement" is a more helpful term than that of "cohesion," which is the language of aspiration. For example, none of the schools in our study spoke of community cohesion in a way that applied greater integration or assimilation: this was contrary to their raison d'etre and focus on cultural sustainability. Instead they were involved in charitable events and curricula initiatives which linked them to the outside world on their terms. In this way, community "engagement" is achievable immediately. Gaine (2005) and Carroll (2003) have conducted work on community engagement suggesting that the concept can be explained as fully engaged, vicariously engaged, semi engaged, and under engaged. Similarly, Dyson and Gallannaugh (2008) conceptualize this in terms of levels with "six steps to engagement."

Building on this literature and informed by our findings, we propose another typology of engagement for schools. This is based on a spectrum which demonstrates the different levels of engagement:

- Meaningful engagement (significant interaction) 
- Sustained engagement (strong evidence of different forms such as knowledge of and interaction with other faiths/wider community on a regular basis)

- Temporary engagement (perhaps due to one teacher or member of the school community but not sustained because that person has left or the strategy is discontinued)

- Tokenistic engagement (a one off event or trip, assembly meeting)

- Superficial engagement (a veneer but weak and of no consequence)

- No engagement (Ethnocentric, mono-cultural, Eurocentric in curriculum, school ethos)

We suggest that future research should focus on producing "a cohesion school development plan," identifying priorities, establishing values, and developing the curriculum. It should be possible for schools to map the different levels of awareness and commitment to action of different stakeholders within the school. This would avoid activities of engagement being carried out by only one group such as teachers and would require pupils and parents to have relevant opportunities. In our study there was evidence of associational engagement (Varshney, 2002) with more formal political and civic interaction. For example, having connections with groups in Israel or Palestine featured as important for schools in our sample. It also relates to groups within the same religious tradition. Our typology of engagement would, therefore, extend to all stakeholders and be operationalized at a number of levels within and beyond the faith grouping.

Cantle (2006) reflected five years after his initial report into the riots in Oldham that the town now needs to modify its community cohesion strategy, particularly with a view to setting clear objectives, priorities, and targets. "There should be a clear indication of what is critical to success and a set of core initiatives around which the new programme is built" (p.53).

Based on our empirical study we concluded somewhat differently. Community engagement is a more likely goal than community cohesion, which is the language of aspiration and rhetoric. It is unclear what should be cohered around and whose values should underpin cohesion. What are the deliverables and how should we recognise them? The various definitions of community imply that cohesion does not simply mean within a community but politically it implies beyond the immediate community (Parker-Jenkins et al., 2005). As such we reject the concept of "cohesion" in its present, simplistic form. Hostility is a real challenge to engagement or cohesion. Further, from our study we found that children are more vulnerable than adults to incidents of Islamophobia and antiSemitism. There is little research on this, and in our study we found incidents went unreported or stayed between children and parents. Both have implications for the way cohesion is to be understood. 


\section{Implications for Policy and Practice in Schools}

All schools in the United Kingdom are obliged to implement instruction to foster community cohesion, but there has been a particular emphasis on faithbased schools to do so. That is because they have been singled out for and criticised due to their self-imposed segregation. The Berkeley Report (Berkeley \& Savita, 2008) stated that "commitment to the promotion of cohesion is not universal, and for many faith schools, not a priority" (p. 5).

Whilst not wishing to advocate for or denigrate faith-based schools, we would contend that the same could also be said of many non-religious schools. Also, it could be argued that the existence of "good race relations" may remove the inclination for school communities in the United Kingdom to be proactive in advancing community cohesion set alongside a competing school agenda characterised by academic attainment, assessment, and national government school league tables.

As we have argued in this article, the pursuit of "community cohesion" is the language of aspiration, and for some schools "community engagement" might be a more realistic starting point. Parker-Jenkins, Hartas, and Irving (2005) raised the question, "Do we ask enough of faith-based schools in terms of community engagement on behalf of their pupils?" From this follow-up research we have discovered that many faith-based schools use a number of strategies for community engagement at micro, meso, and macro levels. The recent government initiative causes them and community schools to reflect on what has been achieved so far and how they should respond to the legal rather than voluntary requirement. As such, the implications for schools center on a number of key issues.

Initiatives designed to bring children together from different faith-based and non faith-based schools should be structured around cooperation, not competition, which traditionally tends to characterise inter-school activities. Community schools of no religious affiliation should also seek opportunities for pupils to mix and develop their own understanding and valuing of cultural diversity beyond their school community; parents, not just teachers or pupils, will need to be brought on board in this initiative. Schools will need to work hard to gain the support of parents, many of whom have chosen a faith-based school for their children precisely because they do not want them to mix with children of other backgrounds. For example, one Jewish school principal said, "The main reason the parents choose this school is because we have nice children here, they mix with other Jewish children." This was validated by her peer in a neighbouring school who said:

You have those families that actually quite unashamedly send their children to $X$ because it is a good white school. This is predominantly Asian; we are in a little island here. If you go to the school around the corner, you would see at least $90 \%$ Asian families. 
Similarly, a deputy head teacher of a liberal Jewish school said:

If you want to be really cynical, you could also look at some Jewish schools...partly as a result of inverse racism, or self-segregation of Jewish parents that don't want their kids to be with Asian and Black... I think there are pressures not to be part of a wider society...there are pressures to be part of the Jewish community, you want your kids to grow up and marry other Jews, for a lot of parents that is a factor when choosing a Jewish school.

The Ouseley Report (2001), in its review of race relations and the failure to prepare young people for life in a multicultural society, highlighted "a virtual apartheid" between schools. Likewise, the Cantle Report (2001) highlighted how distinct religious or ethnic communities can live within metres of each other but have no social bonds or shared cultural capital. Government is said to be keen to tackle this problem and sees the role of schools as paramount to the agenda, particularly in the light of violent acts of terrorism perpetrated in the name of religion. Resistance to effective engagement between schools will mean that the notion of "community cohesion" is left to the goodwill of schools, and potentially government inspection at a rudimentary level will mean that the policy may remain at the level of pious but empty rhetoric.

\section{Conclusion}

This research set out to investigate the ways in which Jewish and Muslim faith-based schools approach community cohesion. These school communities seek to protect themselves against threats of identity erosion and against Islamophobia and anti-Semitism, through influence over the education of their children in faith-based schools and by creative cohesion around their respective faiths within a school. Since the riots in England in 2001, the Government has been obliged to think strategically about how a level of community cohesion could be achieved in a multicultural society. In an endeavour to work towards this goal, schools have been tasked to help support the agenda through activities with pupils. Given the government agenda of financial support for faith-based schools, it is difficult to avoid new dividing lines or prevent the spiral of separation. These are evolving issues in the United Kingdom and in other countries seeking to balance competing perspectives and parental choice, yet trying to cohere around a set of markers or values which provide a bonding mechanism for the wider community. What would be required is unprecedented collaboration between communities to ensure that cohesion is preserved; at this time we are still at the early stages of engagement. As such we need to consolidate the more readily attainable initiatives of community engagement and consider more carefully the rationale and strategy which might make community cohesion achievable. 


\section{Notes}

1. This study was supported by a grant from the UK Economic and Social Research Council. We are grateful to this funding body, and we also wish to acknowledge the support of the school communities. Thanks go also to Huma Shanthu for assistance with the data collection during the inquiry 2007-8, and Research Assistant Emmanuel O'Grady, University of Limerick, who worked on the final preparation stage of this paper.

2. Direct quotations from the qualitative data from this article are provided without editing.

\section{References}

Association of Muslim Schools (2009). AMSUK. Retrieved from http://www.amsuk.org/

Bekerman, Z., \& McGlynn, C. (2007) Addressing ethnic conflict through peace education: International perspectives. London: Palgrave Macmillan.

Berkeley, R., \& Savita, V. (2008). Right to divide?: Faith schools and community cohesion. London: Runnymede Trust.

Brown, A. (2003). Church of England schools: Politics, power, identity. British Journal of Religious Education, 25(2),103-116.

Cantle, T. (2001). Cantle Report: Community cohesion: A report of the Independent Review Team. London: HMSO.

Cantle, T. (2006). Parallel lives. Index on Censorship, 35(2) 85-90.

Carroll, P. (2003). 'Race' and citizenship after 2000: Educational policy and practice. Unpublished thesis: University College Chichester. United Kingdom.

Catholic Education Service (1997). The Catholic schools and other faiths report. London: CES.

Catholic Education Service (1999). Evaluating the distinctive nature of the Catholic school. London: CES.

Clyne, D. I. (2000). Seeking education: The struggle of educating Muslim children in Australia. Unpublished PhD thesis, University of Melbourne, Australia.

Coleman, J. S. (1994). Foundations of social theory. Cambridge, MA: Belknap Press.

Community Security Trust. (2010). Protecting the Jewish community. Retrieved from http://www.thecst.org.uk/. 
Denham, J. (2001). Building cohesive communities: A report of the ministerial group on public order and community cohesion. London: Home Office.

DfEE/QCA (1999). History: The national curriculum for England. London: HMSO.

Department for Education and Skills (2003) Religious education in faith schools. London: DfES.

DCSF (2007) Guidance on the duty to promote community cohesion. Retreived from

http://www.cohesioninstitute.org.uk/resources/Publications/Guidance\%200 n\%20the\%20duty\%20on\%20schools\%20to\%20promote\%20cc.pdf

DCSF (2010) Schools, pupils and their characteristics: Retrieved from http://www.education.gov.uk/rsgateway/DB/SFR/s000925/index.shtml

Dyson, A., \& Gallannaugh, F. (2008). School-level actions to promote community cohesion: A scoping map. Technical report. In Research Evidence in Education Library. London: EPPI-Centre, Social Science Research Unit, Institute of Education, University of London.

Education and Inspections Act (2006). Chapter 40. Her Majesty's Stationery Office: London.

EUMC / European Monitoring Centre on Racism and Xenophobia. (2009). A working definition of anti-Semitism. Retrieved from http://eumc.europa.eu/eumc/material/pub/AS/AS-WorkingDefinitiondraft.pdf

Furbey, R., Dinham, A., \& Farnell, R. (2006). Faith as social capital: Connecting or dividing? York, UK: Rowntree Foundation.

Gaine, C. (2005). We're all White thanks. Stoke-on-Trent, UK: Trentham Books.

Gaine, C. (1995). Still no trouble here. Stoke-on-Trent, UK: Trentham Books.

Gilroy, P. (1987). There ain't no black in the Union Jack. London: Hutchinson.

Gillborn, D. (1995). Racism and antiracism in real schools. Buckingham, UK: Open University Press.

Gülen, F. (2005). An interview with Gülen by Zeki Saritoprak and Ali Ünal. The Muslim world Special issue, 95(3), 447-467.

Hewer, C. (2001) The essence of Islam, London: RP Publishing.

Hollinger, D. (1995). Postethnic America: Beyond multiculturalism. New York: Basic Books.

Home Office (2001) Ethnicity. London: Home Office.

Hornsby-Smith, M. (2000). The changing social and religious content of Catholic schooling in England and Wales. In M. Eaton, J. Longnore, and A. Naylor (Eds.) Commitment to diversity: Catholics and education in a changing world (pp. 184-209). London: Cassell. 
Husain, F., \& O'Brien, M. (1999). Muslim families in Europe: Social existence and social care, report for ED-DGV. London: University of North London.

The grown-ups need to grow up. (2007, February 18). The Independent, p.38.

Jayaweera, H., \& Choudhury, T. (2008). Immigration, faith and cohesion Evidence from local areas with significant Muslim populations. York: Joseph Rowntree Foundation.

Kincheloe, J. L., \& Steinberg S. R. (1997). Changing multiculturalism. Buckingham, UK: Open University Press.

Lankshear, D. (2001). The relationship between church schools and local church life distinguishing between aided and controlled status. Educational Studies, 27(4), 425-438.

Larkin, R. W. (2007). Comprehending Columbine. Philadelphia: Temple University Press.

Local Government Association (2002). Guidance on Community Cohesion Communities and Local Government. Retrieved from http://www.neighbourhood.gov.uk/page.asp?id=1200

MacMullen, I. (2007). Faith in schools? Autonomy, citizenship, and religious education in the liberal state. Princeton, NJ: Princeton University Press.

Michel, T. (2006). Gülen as educator and religious leader (A summary of the paper presented by Father Thomas Michel, in the Fetullah Gülen Symposium held at Georgetown University, April 2001). Retrieved from http://www.fethullahgulen.org/press-room/review/1054-gulen-as-educatorand-religious-teacher.html

Miller, H. (2007). Accountability through Inspection: Monitoring and evaluation of Jewish Schools. London: Pikuach.

Miller, H. (2001). Meeting the challenges: The Jewish schooling phenomenon in the UK. Oxford Review of Education, 27(4), 501-513.

Modood, T. (2005) Multicultural politics: Racism, ethnicity and Muslims in Britain. Edinburgh, UK: Edinburgh University Press.

Nielsen, J. S. (2000). Fluid identities: Muslims and Western Europe's nation states. Cambridge Review of International Affairs, 13(2), 212-227.

Office of National Statistics (2006). Focus on ethnicity and religion. Basingstoke, UK: Palgrave Macmillan.

O'Keefe, B. (1997). The changing role of Catholic schools in England and Wales: From exclusiveness to engagement. In J. McMahon et al. (Eds.). Leading the Catholic school. Victoria NSW, UK: Spectrum Publications.

Ouseley Report (2001). Community pride and prejudice: Making diversity work in Bradford. Bradford, UK: Bradford City Council.

Parekh, B. (2002). 'Common belonging', in cohesion, community and citizenship. London: The Runnymede Trust. 
Parker-Jenkins, M. (1995). Children of Islam. Stoke-on-Trent, UK: Trentham Books.

Parker-Jenkins, M. (2002). Equal access to state funding: The case of Muslim schools, Race, Ethnicity and Education, 5(3), 273-289.

Parker-Jenkins, M. (2008). Sparing the rod: Reflections on the abolition of corporal punishment, and the increase in violence in British classrooms. Australia and New Zealand Journal of Law and Education, 13(1), 7-20.

Parker-Jenkins, M., Hartas, D. \& Irving, B. (2005). In good faith: Schools, religion and public funding. London: Ashgate Publishers.

Parker-Jenkins, M., Hewitt, D., Brownhill, S., \& Sanders, T. (2007). Aiming high: Raising attainment of pupils from culturally-diverse backgrounds. London: Paul Chapman Educational Publishing.

Pearce, S. (2005). You wouldn't understand: White teachers in multiethnic classrooms. Stoke-on-Trent, UK: Trentham Books.

Pugh, G., \& Telhaj, S. (2007). Faith schools, social capital and academic attainment: Evidence from TIMSS-R mathematics scores in Flemish secondary schools. British Educational Research Journal, 34(2), 235-267.

Runnymede Trust (1997). Islamophobia: A challenge for us all. London: Runnymede.

Runnymede Trust (2008). Right to divide? Faith schools and community cohesion. Retrieved from

http://www.runnymedetrust.org/uploads/publications/pdfs/RightToDivide 2008.pdf

Sacks, J. (2007). The home we build together: Recreating society. London: Continuum International Publishing Group.

Schmool, M., \& Cohen, F. (1998). A profile of British Jewry. London: Board of Deputies of British Jews.

Short, G., \& Lenga, R. (2002). Faith schools and social cohesion: Opening up the debate. British Journal of Beliefs and Values, 25(1), 43-54.

Mansell, W., \& Barnard N. (2001, 5 October). Faith schools: Opposition multiplies. Times Educational Supplement, p.1.

Troyna, B., \& Carrington B. (1990). Education, racism and reform. London: Routledge.

Varshney, A. (2002). Ethnic conflict and civic life: Hindus and Muslims in India. New Haven, CT: Yale University Press.

Walford, G. (2001). Funding for religious schooling in England and the Netherlands: Can the piper call the tune? Research Papers in Education, 6(4), 359-380. 
Weller, P. (2003). Identity, politics and the future(s) of religion in the UK: The case of the religion question in the 2001 Decentennial Census, Journal of Contemporary Religion, 9(1), 3-21.

Zine, J. (2007). Safe havens or religious 'ghettos'? Narratives of Islamic schooling in Canada. Race Ethnicity and Education, 10(1), 71-92. 